\title{
Trajetórias divergentes da ciência na Argentina e no Brasil
}

\author{
The different paths of science in \\ Argentina and Brazil
}

\author{
Silvia Figueiroa \\ Universidade de Campinas (Unicamp) \\ Departamento de Ciências Aplicadas/Instituto de Geociências \\ Caixa Postal 6152 \\ 13081-970 Campinas — SP Brasil \\ figueroa@ige.unicamp.br
}

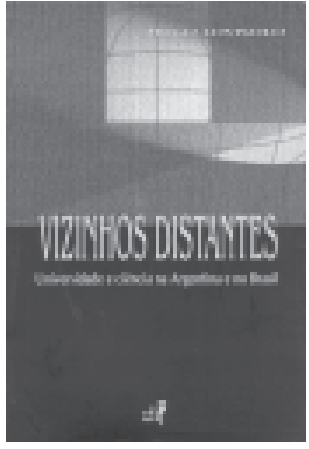

Vizinhos distantes: universidade e ciência na Argentina e no Brasil

Hugo Lovisolo Rio de Janeiro, EdUERJ, 2000, 132p.
$\mathrm{O}$ livro de Hugo Lovisolo, escrito numa prosa clara, fluente e não uniforme, ao mesmo tempo que conceitualmente precisa, parte de um tema rico e de um problema oportuno: realizar um estudo comparativo entre o desenvolvimento científico da Argentina e do Brasil, que, apesar das muitas semelhanças, seguiram caminhos distintos. O autor se pergunta, já desde o início, o que interessa às comunidades científicas de muitos países, particularmente as latino-americanas: "historicamente, desde a conquista, os vizinhos próximos herdaram tradições religiosas, políticas, culturais e posições econômicas estruturais bem mais semelhantes do que na comparação com os vizinhos distantes ... . Diante do pano de fundo das semelhanças, emerge então com naturalidade a questão geral: como e por que foram geradas as diferenças" (p. 9). O período tratado vai, grosso modo, de 1900 a 1970, mas o século XIX acaba sendo englobado por conta da análise, imprescindível, da influência do positivismo, com suas nuanças e matizes, em ambos os países.

As 132 páginas dividem-se em cinco capítulos, além da 'Introdução', na qual o autor apresenta o livro, suas intenções e premissas, e adiciona os agradecimentos. Sua premissa básica é que, em princípio, desenvolvimento econômico e desenvolvimento científico e cultural caminham juntos. Nos dois casos sob análise essa relação não é direta, o que conduz a um paradoxo que terá função heurística, como explica o autor já na primeira página. Outra premissa importante é que comparações com não-vizinhos, principalmente com os freqüentemente citados Estados Unidos, Inglaterra e França, por haverem sido já muito exploradas, estariam agora, de certo modo, esgotadas como desafio intelectual, e portanto valeria a pena apostar na comparação com a América Latina.

No primeiro capítulo, 'Positivismo: influências e interpretações', Lovisolo explora a penetração do ideário positivista nos dois países levando em conta um duplo movimento: de um lado, as diferenças entre as vertentes teóricas escolhidas e, de outro, as diferentes formas de apropriação desse conjunto de idéias, que são lidas em função dos respectivos processos históricos ao mesmo tempo que fazem uma leitura desses mesmos processos. No segundo capítulo, 'Einstein, uma viagem, duas visitas', o autor discute as profundas diferenças entre as estadas de Albert Einstein na Argentina e no Brasil, embora ocorridas em seqüencia temporal, ressaltando a partir disso a diversidade dos contextos políticos, sociais e 
científicos da época, que permitiram, inclusive, que o cientista tivesse discursos e comportamentos flagrantemente divergentes. No terceiro capítulo, 'A legitimação da ciência na fronteira', Lovisolo empolga-se com uma aquisição feita numa livraria em Buenos Aires: a $6^{\mathrm{a}}$ edição do livro Reglas y consejos sobre la investigación científica: los tónicos de la voluntad do espanhol Ramón y Cajal, prêmio Nobel. Partindo daí, do texto do livro e de anotações feitas no exemplar por alguém que o possuiu anteriormente, Lovisolo discorre, refletindo, sobre as agruras do fazer científico nos países que estão fora dos centros da ciência. O quarto capítulo, 'Comunidades científicas e universidades na Argentina e no Brasil', discute as atuações estratégicas diferenciadas das comunidades científicas argentina (cientificista ou intervencionista) e brasileira (academicista ou de renúncia), cujos desdobramentos estão bem presentes até hoje: democratização do ensino e baixa legitimação da comunidade científica na Argentina e, ao contrário, elitização da educação e qualificação da atividade científica no caso do Brasil. O quinto capítulo, 'Considerações finais', apresenta reflexões finais e aponta pontos e temas de investigação promissores a fim de melhorar o quadro mostrado no livro.

Apesar do visível esforço de pesquisa, da pertinência do tema e do interesse das conclusões, é uma pena que o autor não tenha aproveitado em suas reflexões toda uma produção - nem tão recente assim, posto que já tem vinte anos - que tem tido sucesso em suas preocupações em pensar e mostrar a ciência e a tecnologia latino-americanas sob novos prismas. Para não me alongar em exemplos, citarei apenas dois casos em que essa ausência pareceu-me lamentavelmente gritante. O primeiro deles no capítulo sobre a visita de Einstein: Lovisolo vale-se, para falar do Brasil, exclusivamente de um artigo de Cafarelli publicado em 1979 em Ciência E Cultura, quando, em 1995, Ildeu de Castro Moreira e Antônio Augusto Passos Videira publicaram um livro inteiro dedicado ao tema. Outro exemplo refere-se ao capítulo sobre a ciência na fronteira: não indo além em referências sobre uma das questões mais debatidas pela recente historiografia latino-americana das ciências e da tecnologia, bastaria o autor conhecer o livro de Marcos Cueto sobre excelência científica na periferia. Igualmente, suas reflexões ganhariam em muito se, em vez de se restringir a usar, um tanto acriticamente, autores "clássicos" como Merton, Popper, Ben-David, Kuhn ou Lakatos, o autor se valesse das obras dos estudos sociais da ciência e da tecnologia, que há três décadas vêm propondo novas formas de compreender o complexo ciência \& tecnologia em suas múltiplas inter-relações com os contextos históricos e locais. Não se trata, aqui, de uma crítica "punitiva" ao autor, mas de lamentar que esse tipo de ausência tenha impedido Lovisolo de avançar ainda mais suas efetivas contribuições ao tema. 
SILVIA FIGUEIROA

\section{REFERÊNCIAS BIBLIOGRÁFICAS}

Moreira, Ildeu de C. e

Einstein e o Brasil.

Videira, Antonio A. P. Rio de Janeiro, Ed. UFRJ, 284p.

(orgs.)

1995

Cueto, Marcos

1989

Excelencia científica en la periferia (actividades científicas e investigación biomédica en el Peru, 1890-1950). Lima, Grade: Conycet, 230p. 